\title{
Recipient age as a modifier of outcomes and risk factor for complications following heart transplantation
}

\author{
Ivo Planinc*, \\ Dora Fabijanović, \\ Jana Ljubas Maček, \\ Boško Skorić, \\ Hrvoje Jurin, \\ Jure Samardžić, \\ Nina Jakuš, \\ Hrvoje Gašparović, \\ Maja Čikeš, \\ Davor Miličić
}

University of Zagreb School of Medicine, University Hospital Centre Zagreb, Zagreb,

Croatia
RECEIVED:

September 24, 2017

ACCEPTED:

September 26, 2017

\section{KEYWORDS: age, heart transplantation, outcome, vasculopathy, rejection.} CITATION: Cardiol Croat. 2017;12(9-10):367. | https://doi.org/10.15836/ccar2017.367

*ADDRESS FOR CORRESPONDENCE: Ivo Planinc, Klinički bolnički centar Zagreb, Kišpatićeva 12, HR-10000 Zagreb, Croatia. / Phone: 385-98-525-449 / E-mail: ivo.planinc@gmail.com

ORCID: Ivo Planinc, http://orcid.org/0000-0003-0561-6704 • Dora Fabijanović, http://orcid.org/0000-0003-2633-3439 Jana Ljubas Maček, http://orcid.org/0000-0001-7171-2206 • Bosko Skorić, http://orcid.org/0000-0001-5979-2346 Hrvoje Jurin, http://orcid.org/0000-0002-2599-553X • Jure Samardžić, http://orcid.org/0000-0002-9346-6402 Nina Jakuš, http://orcid.org/0000-0001-7304-1127 • Hrvoje Gašparović, http://orcid.org/0000-0002-2492-3702 Maja Čikeš, http://orcid.org/0000-0002-4772-5549 • Davor Miličić, http://orcid.org/0000-0001-9101-1570

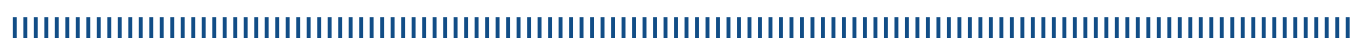
Introduction: Age is one of the important factors when considering a patient for heart transplantation. Over the last decades there was a clear upper age limit when heart transplantation was not recommended due to shortage of donors and worse expected survival. However, more recently it has been increasingly shown that both ends of the age spectrum have different mortality rates, as well as incidence of specific post-transplantation complications. ${ }^{1,2}$ The aim of this study was to evaluate outcomes and complications of different age groups of heart transplant recipients from our Centre.

Patients and Methods: We retrospectively collected data from 170 consecutive heart transplant recipients from our Centre in the period from January 2008. To August 2017. (median age 56 years, age distribution 15-70 years, 133 males, median follow-up 26 months, follow-up distribution 0-113 months) The patients were grouped by quartiles of age: 15-46 years (q1), 47-56 years (q2), 57-62 years (q3), 63-70 years (q4). The primary outcome of the study was overall survival; secondary outcomes were cellular and antibody-mediated rejection requiring treatment, graft vasculopathy, and infections. Pearsons $\mathrm{x}^{2}$ test was used for group comparison, while for overall survival Kaplan-Meier curves were calculated.

Results: As shown on Figure 1 a significant difference in the primary outcome was found among the age groups, with the worst survival in the highest age quartile ( $\mathrm{p}=0.01)$. Significant differences in the occurrence of several secondary outcomes were found as well: rejection episodes were more frequent in the lowest age quartile $(\mathrm{p}=0.01)$, while the occurrence of both fatal and non-fatal infections $(\mathrm{p}=0.04$, and $\mathrm{p}<0.01)$, as well as the occurrence of neoplasms was higher in highest age quartile $(\mathrm{p}=0.04)$.

Conclusion: Our retrospective study confirms significant differences in outcomes and post-transplantation complications among patients of different age groups, warranting a more individualized treatment ap-

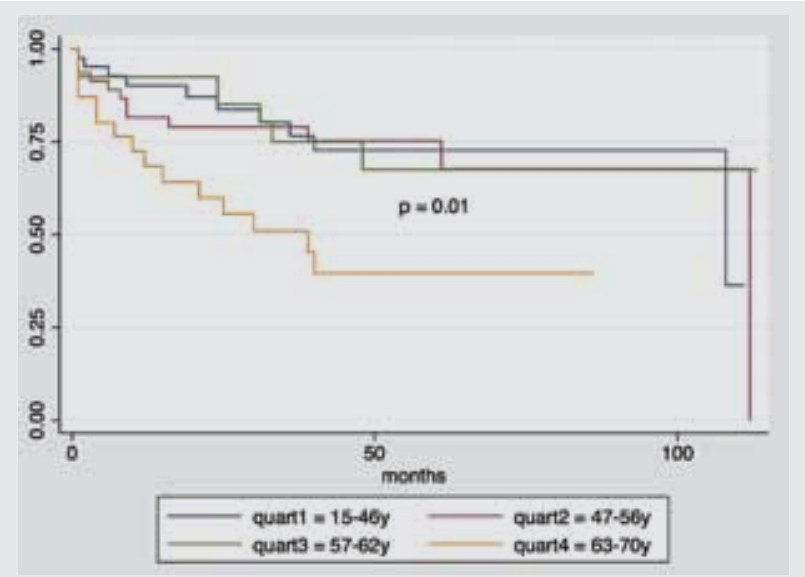

FIGURE 1. Overall survival among quartiles of age presented as Kaplan-Meier curves.

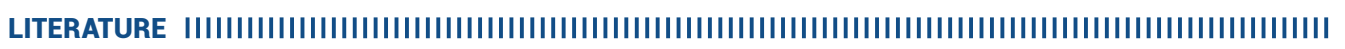

1. Wever-Pinzon 0, Edwards LB, Taylor D0, Kfoury AG, Drakos SG, Selzman CH, et al. Association of recipient age and causes of heart transplant mortality: Implications for personalization of post-transplant management-An analysis of the International Society for Heart and Lung Transplantation Registry. J Heart Lung Transplant. 2017 Apr;36(4):407-417. https://doi.org/10.1016/j.healun.2016.08.008

2. Awad M, Czer LS, Mirocha J, Ruzza A, de Robertis M, Rafiei M, et al. Similar Mortality and Morbidity of Orthotopic Heart Transplantation for Patients 70 Years of Age and Older Compared With Younger Patients. Transplant Proc. 2016 0ct;48(8):2782-2791.

https://doi.org/10.1016/j.transproceed.2016.06.039 